\title{
The role of teacher-child interaction in promoting peer communication
}

\author{
Natalia S. Denisenkova ${ }^{\mathrm{a}}$, Anastasia K. Nisskaya ${ }^{\mathrm{b}^{*}}$ \\ a Social Psychology Faculty, Moscow State University of Psychology and Education, \\ Moscow, Russia \\ b Institute of Education, National Research University "Higher School of Economics", \\ Moscow, Russia \\ *Corresponding author. E-mail: Anastasiya-Nisskaya@yandex.ru
}

It is well-known that communication is the main source and necessity of human development and activity. It promotes social relationships, self-image and a wide range of cognitive and non-cognitive skills. Preschoolers communicate both with their peers and adults. It is traditionally assumed that peer communication greatly depends on the teacher-child interaction, leading role of the adult, and the child's own activity, which are the main elements of the Russian preprimary education system.

Changes in social situations, reductions in available play time, greater engagement of children in activities and many other factors can affect modern preschoolers' peer communication. Therefore, the effect of teacher-directed and child-directed teacherchild interactions on preschoolers' peer communication important to study.

The following methods were applied: peer-communication observation, the behavioral tests 'Magic room' and 'Mosaic', and the sociometric procedure 'Two houses'. The sample included 49 Moscow preprimary students aged 4 to 6 year old (25 girls and 24 boys).

The research proved that preschoolers showed better results in child-directed interactions, such as playing skills, compared with a similar situation in which the children were directed by the teachers. Additionally, the level of proactiveness, communication success, conflict resolution, prosocial behavior and emotional response to peer influence did not differ among children.

Thus, the child-directed approach is more beneficial to preschoolers' communication development than a teacher-directed approach.

Keywords: teacher-child interaction, preschoolers' peer-communication, peer-communication components, preprimary education 


\section{Introduction}

\section{Peer-communication is an important part of preschoolers' development}

According to the Federal Educational Standards (Federal State educational standard of preschool education, 2013), the aim of preprimary education is to provide autonomy, independence, responsibility, initiative and other social-emotional skills. One of the most important educational targets is highly developed communicative competence and abilities, particularly in peer-communication. The importance of peer-communication in preschool childhood is obvious. It can have a favorable effect on developing cognitive skills, pro-social behavior, emotional comfort and so on. Intensification of peer-communication in preschool childhood provides high educational outcomes. It is important to incorporate and coordinate various perspectives and accumulate knowledge in developing communication skills during childhood (Tartas, Baucal, Perret-Clermont, 2010; Flavell, 1981).

Peer-communication ensures critical thinking, objectivity and reflexivity. Communication is a predictor of cognitive development. Moreover, peer-communication fosters prosocial behavior, prevents bullying and contributes to a favorable emotional climate in class (Eisenberg, Mussen, 2011). Therefore, it is important to determine how to develop and research the role of teacher-child interactions in the formation of peer-communication during childhood.

According to L.S. Vygotsky, peer-communication is an objective necessity in child development (Vygotsky, 2008) and a special activity. Interactions with others and self-image depend on it. Communication and relationships can be developed by playing with peers (Smirnova, Kholmogorova 2005; Zaporogets, Lisina, 1974).

Preschooler's peer-communication is complicated and is a holistic system with special strict and evolutional dynamics. At the age of 5-7 years, children's relationships become more selective and stable. At this stage, there are stable groups of friends. Preschoolers tend to spend more time playing and talking with peers. Peers' opinion and access become very influential. Preschoolers attach to each other and have stable attractions and preferences. The group of peers becomes diverse, and it is possible to have different stable groups of friends and to access a sociometric structure.

Preschoolers' peer-communication can be analyzed by assessing proactiveness, favorable positions, successful communication, playing skills, frequency of conflicts, conflict coping method, behavior during conflict, sociometric structure of the group, pro-social behavior and emotional involvement in peers' actions (Smirnova, Kholmogorova 2005; Zaporogets, Lisina, 1974; Smirnova, Galiguzova 2005).

Proactiveness is a child's ability to create clear ideas and various proposals for cooperative play. Successful communication depends on how many partners the child chooses for imaginative play. Playing skill is the ability of a child to engage in role-playing games or a game with rules, assign roles, and perform them consistently to expand the game's plot. The frequency of conflicts is the number of conflicts that include the child. Conflict coping methods involve the successful choice of the method of conflict resolution. The sociometric structure of the group involves a relationship of sympathy or antipathy within the group. Pro-social behavior is a child's means of communication with children, contributing to the successful organization of joint activities. Emotional involvement in the peers' actions 
means the desire and willingness of the child to perceive the actions of peers and to respond to his proposal.

Changes in the general social situation, shifts in educational and training priorities, reduction in time allocated to play and for free activities, and the emergence of new methods of interaction, including computer games, a large engagement of children and many other factors affect the dialog of modern preschool children with their peers and their ability to choose their partners, to organize joint play and other activities, to resolve conflicts, to understand other people, and so on (Smirnova, Galiguzova, 2005; Sobkin, Skobeltsina, 2012; El'koninova, 2014). In this regard, the role that this process plays in the educational environment of preschool institutions, in which children spend most of their time, is important. It is traditionally assumed that peer-communication development highly depends on the conditions of upbringing. International studies have shown that early educational experience is very important for further wellbeing (McCain M., Mustard J.F., 1999). Daily practice of pre-school education helps to achieve the required level of social development.

Additionally, most children spend a major part of their day in a preschool institution that is associated with the experiences and interests of the child. According to the ecological approach, taking into account the role of this field in the real life of the child will enable significant progress in preschoolers' development and well-being (Pianta, Rimm-Kaufman, \& Cox, 1999). Daily practice of pre-school education helps to achieve the required level of intellectual, personal and social development.

Research on pre-school education quality was the subject of multiple publications in recent years, gaining widespread popularity after the article by George Hackman in 2006. In that article, he demonstrated the importance of kindergarten as a whole and the quality of educational programs in particular. The mere fact of attending kindergarten (or other pre-school organizations) has been recognized as beneficial for the child, contributing to his future success and well-being (Heckman, Tremblay, 2006).

Nevertheless, the exact "driving force" in this effect remains insufficiently disclosed. The current debate is what comprises a high quality pre-school education.

\section{Teacher-child interaction in preschool childhood}

The importance of the teacher-child interaction, leading role of adults, and significance of a child's own activity are basic theoretical frameworks on which Russian preprimary education is based. The importance of the child-adult interaction has been highlighted in the fundamental basic theory of development and education (Vygotsky, 2008; Polivanova, 2012).

Effective teaching in early childhood education and care (ECEC) should include sensitive and warm interactions, responsive feedback, and verbal communication, and preference should be given over the structured and highly regulated approach.

A not overly structured interaction provides good results in literacy and social development (Downer, Sabol, Hamre, 2010). Trust and a close teacher-child interaction can decrease aggressiveness and provide pro-social behavior (Birch \& Ladd, 
1988; Graves, Howes, 2011; Locasale-Crouch, DeCoster, Pianta, 2013). Recent research has also demonstrated associations between the teacher-child interaction and school-readiness. Good teacher-child interactions provide high scholastic achievements (Scott-Little, La Paro, Thomason, Pianta et al., 2011).

The teacher-child interaction is an important condition of preschooler development. It occurs in preprimary settings based on various approaches (teacherdirected or child-directed).

\section{Models of teacher-child interaction}

Based on the findings of V. A. Petrovsky, we have identified several patterns of interactions between the teacher and child: the "non-interference", educationaldisciplinary and personality-oriented models (Petrovsky, 1996).

"Non-interference" model. In this model, the teacher stays indifferent to the child, sees him or her as an interference, does not provide support and avoids responsibility.

"Educational-disciplinary" model of interaction. The purpose of this interaction is to enlighten the child with knowledge, skills and abilities. In this model, the child is a passive object of the adult's influence and only adjusts to him. Typical methods of interaction in this model are punishment, prohibition, instruction, explanation or threat.

In foreign studies, a similar model is called teacher-directed interaction. In this report, we will use these terms interchangeably.

Recent research has proven that the teacher-directed interaction provides better learning, motivation and language development for low-income preschoolers. The children showed high task performance as well as positive emotions and affect at the end of the test (Anders, 2014). Teacher-managed activities had a positive effect on the development of language, literacy and mathematical skills in preschool children (De Haan, Elbers and Leseman, 2014). Children showed relatively low results in motivation measures (dependency on adults, self-esteem, beliefs in the success of their own accomplishments) (Stipek, Feiler, Daniels et al., 1995).

The teacher-directed teacher-child interaction can successfully promote children's learning, but the effects often seem to be short-termed and may diminish very quickly (Kuger, Sechtig, \& Anders, 2012).

Personality-oriented interaction model. The teacher seeks to provide the child with a sense of psychological security and confidence in the world and to develop his personality. The child is an active participant in the interaction. A typical interaction is a partnership dialogue, promotion of independence, activity stimulation, and use of problematic situations. This model is often described as the child-directed model of interaction and assumes relationships of cooperation and partnership between adults and children, a combination of the goals of individualization and socialization. The teacher-child interaction is characterized by goodwill, an individual approach, and promotion of freedom and educational initiatives of children and excludes punishment (Rubtcov, 2005; Bulichova, 2012). Recent research has proven that the child-directed interaction provides a wide range of benefits. Marcon (1999) showed positive effects in acquiring basic, receptive and language skills as well as personal and interpersonal skills. The study by Lerkkanen and colleagues 
found that a child-directed model of interaction was positively associated with the development of children's interest in reading and mathematics (Lerkkanen and colleagues, 2012).

Children who took part in preschool programs that used the child-directed teacher-child interaction model demonstrated higher self-efficiency and self-esteem on academic achievement, were less independent on adults, were more proud in their own accomplishments and were less worried about school later. Therefore, in regard to socio-emotional factors that later affect academic achievement, the child-directed teacher-child interaction model seems to be highly effective.

The study of the connection between the teacher and child as well as the development of peer-communication has not received substantial attention. Therefore, it is the aim of our study.

\section{Method}

A procedure to detect significant differences by using the Mann-Whitney test was used to analyze the results (significance level $=0.05$ ). These methods were used to estimate indicators, including peer-communication, proactiveness, favorable position, successful communication, playing skills, frequency of conflicts, conflict coping method, behavior in a conflict situation, sociometric structure of the group, and pro-social child behavior and emotional involvement in peers' actions (Smirnova, Kholmogorova 2005; Zaporogets, Lisina, 1974; Smirnova, Galiguzova 2005).

The following methods and procedures were used for the peer-communication study: "Magic room", "Two houses" (Lavrentieva, 2002), observation of children's communication in play situations and free activity, and "Mosaic" (Smirnova, Kholmogorova, 2005).

The "Magic room" procedure is designed to explore proactiveness, successful communication and the development of playing skills and behavior in a conflict situation (frequency of conflicts, conflict coping method).

Procedure. According to the instructions, children are told to imagine that they find themselves in a magic room that contains various games and toys. To get there, they have to observe two conditions: choose two children whom the child will take with him/her and propose what they will do in the magic room.

The psychologist records the child's choice for his/her partners (the number of partners, their age, relationships with the chosen partners: whom he/she is acquainted with or related to). The psychologist also requests that the child suggest an activity.

Then, the psychologist tells the child that his partners are bored and asks the child what he/she is going to do next. The most important factor to determine is how the child reacts to the frustrating situation he/she is faced with. This procedure is repeated three times. At the end of the session, the psychologist thanks the child and praises him/her for his/her creative approach.

Interpretation. The child's initiative and his/her attitude is evaluated on a 4-point scale ( 0 to 3 points) according to the activities proposed by the child, their variety, the roles he/she has taken (a leader or secondary role), the way the child enjoyed the leading role of the communication, and his/her reaction to the imaginary conflict situation that is imposed on the child at the end of the session. 


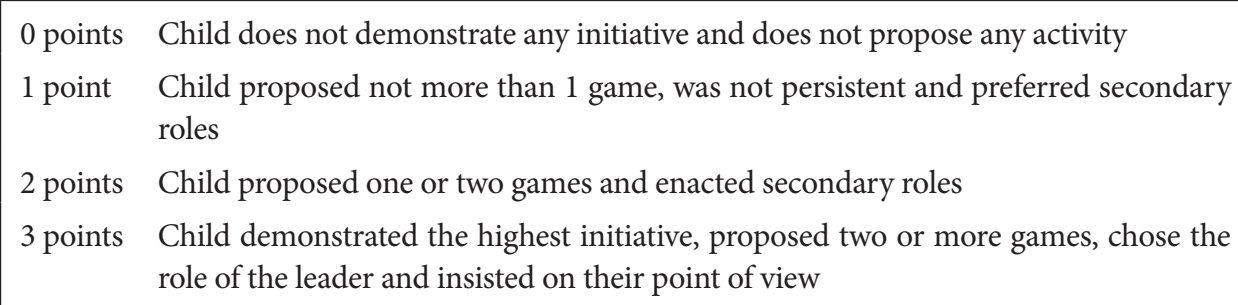

Success in communication is evaluated based on the number of partners the child has chosen and their characteristics. Special attention is paid to the ability of the child to name two or more partners and whether the chosen partners happen to be his/her peers or adults, belong to his/her group or strangers if they are his/ her relatives. The psychologist also records if the child has chosen popular or not popular partners, imaginary partners or animals.

0 points Child does not know whom to choose and plays individually

1 point Child experiences difficulty in making a choice and names one partner, mainly a grown up, a relative, or older or not popular children

2 points Child chooses two children of their own age (at least one of them from the kindergarten group)

3 points Child immediately names two or more children from their group and offers several additional partners after being questioned by the psychologist.

The development of playing skills is assessed based on the child's ability to propose several variations of a game, invent a storyline, and share roles.

0 points Child cannot propose any game or chooses manipulative games or destructive actions

1 point Child proposes one game, mainly a table game, and finds it difficult to name any other possible variations

2 points Child proposes one or two variations of socio-dramatic play or a game with rules in which several children take part

3 points Child easily offers multiple variations of games and is able to talk about the turns, rules and participants

The manner of the child's behavior is assessed on a 3-point scale ( 1 to 3 points) in an imaginary conflict situation (resistance to continue his/her game), constructive or destructive.

1 point Child demonstrates only destructive ways of solving the conflict (showing aggression, trying to escape, asking for assistance from a grown-up)

2 points Child is ready to have a constructive dialogue but wants his/her partner to come up with a decision

3 points Child intends to resolve the conflict constructively, for instance, by offering another game 
The "Mosaic" method is used to examine the pro-social child's behavior and emotional involvement in the peers' actions.

Procedure. Two children take part in the game; each receives a field for a mosaic and a box with colorful elements. Children are asked to race to make mosaic suns on their fields. One of the participants receives mostly yellow elements in his box, and the other receives blue elements. Soon after they start, one of the children notices the lack of yellow elements. In this situation, the child has to ask his peer for help (to give him/her the missing yellow elements). After both of the suns are ready, the psychologist asks them to make a mosaic of the sky above the suns. This time the child faces the lack of blue elements.

Interpretation. The prosocial factor is important. A higher score demonstrates prosocial behavior, which is manifested in the child's ability and willingness to help his peer and provide him with his element of the mosaic, even if he needs it himself.

0 points Child refuses to share his elements of the mosaic even after numerous requests

1 point Child shares his elements unwillingly under pressure from his peer and obviously expects gratitude and emphasizes his help

2 points Child does not refuse to help, but only offers after finishing his/her own task

3 points Child offers the peer his/her elements without any resistance

Emotional involvement in peers' interactions is assessed by the ability of the child to consider the intention of another child and to respond to his/her proposals and feelings. Emotional involvement can be evaluated as positive, negative or demonstrative.

0 points Child ignores other's actions and does not react to them

1 point Child gives negative estimations (abuses or laughs at his/her peers)

2 points Child treats his/her peers with defiance

3 points Child gives positive evaluations and advice and suggests and helps the other child

The "Two houses" method is oriented to reveal the sociometric structure of the group and attractive relationships of children.

Procedure. Two houses are shown to a child (one is red and the other is blue). Then, the child is asked to choose his/her peers from his kindergarten group. Those with whom the child wants to live with are placed in the red house, and the blue house is filled with those whom the child does not want to live with.

Interpretation. Based on the acquired data, the sociometric structure of the group is constructed and the sociometric status, sympathies and antipathies of each child are defined.

The observation of the children's play communication and free activity is used to obtain preliminary data on the child's communication with peers under natural conditions. Proactiveness of communication was estimated according to the following criteria: 


$$
\begin{array}{|ll}
0 \text { points } & \begin{array}{l}
\text { Child did not make any propositions to his peers } \\
1 \text { point }
\end{array} \\
2 \text { points } & \begin{array}{l}
\text { Child seldom agrees to join games and activities or agrees to play roles proposed } \\
\text { Child proposes games and/or other activities and is prepared to take leading or } \\
\text { secondary roles }
\end{array} \\
3 \text { points } & \begin{array}{l}
\text { Child is proactive all the time and is able to insist on his/her point of view and } \\
\text { arrange various games and activities }
\end{array}
\end{array}
$$

Analysis of the frequency of conflicts in which children took part was performed using observation. The observation was conducted for three hours over several days.

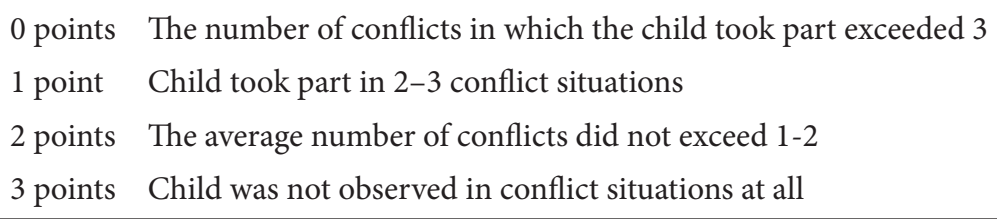

\section{Sample}

The sample included 49 Moscow pre-primary students aged 4 to 6 years old (25 girls and 24 boys).

Twenty-five children attended a private pre-primary institution where the child-directed approach predominates, and the average age of the children was 5 years 1 month.

Many teachers actualize their own education programs in their interactions with children. A conventional system is missing, free zones are allocated to freedom to play, and much time is spent playing and performing other efficient activities. Twenty-four children attended state kindergarten with a teacher-directed approach. Two main teachers interacted with the children according to certain education programs, and the curriculum was based on state standards. Most of the time is spent on specially arranged activities.

Hereafter, the following definitions will be used: sample 1 - children from a child-directed approach pre-primary school; sample 2 - children from a teacherdirected approach pre-primary school.

\section{Results}

\section{Characteristics of the development of preschool child communication}

\section{Proactiveness}

The level of proactiveness of children in both subsamples was determined as low, medium and high (Sample 1 - average score 2.2 points; Sample $2-1.7$ points). Thirty-six percent of children were in a passive position. They refused to play and were not able to make any proposition spontaneously, did not take part in games and activities with other children or passively agreed to play roles offered by other children. These roles were secondary and non-active. 


\begin{tabular}{lcccc}
\hline & Sample 1 & Sample 2 & $\mathbf{U}_{\text {emp }}$ & $\mathbf{U}_{\mathbf{0 , 0 5}}$ \\
\cline { 2 - 5 } Level of proactiveness & 2.2 & 1.7 & 53 & $34-46$ \\
\hline
\end{tabular}

Thirty-six percent of children demonstrated a subdued position. They could propose one or two game alternatives in which they were only passive participants. Their comments over the course of the game were mostly insignificant and connected only with their own role.

The dominant position was taken by $28 \%$ of children. They were leaders in the play situation, preferred to take dominant roles and described the course of the game and distribution of roles.

\section{Communication success}

The following results were obtained for the indices of communication success (Sample $1-$ average score 2.5 points; Sample $2-2.9$ points). Seventy-six percent of children were successful in communication; they found more than two peer partners both in an imaginary situation and in real life. Twenty percent of children demonstrated relative comfort. It took them quite a long time to make their final choice, and their preferable communication partner was usually their brother/sister or a neighbor, but not a child from the group. Only $4 \%$ were not successful in communication. They either refused to name their game partner or preferred to play with animals or parents.

\begin{tabular}{lcccc}
\hline & Sample 1 & Sample 2 & $\mathbf{U}_{\text {emp. }}$ & $\mathbf{U}_{0,05}$ \\
\cline { 2 - 5 } Communication success & 2.5 & 2.9 & 47 & $34-46$ \\
\hline
\end{tabular}

\section{Development of playing skills}

The development of playing skills in the reviewed samples was the following (Sample 1 - average score 2.4 points; Sample $2-1,3$ points): $56 \%$ of children demonstrated a low level, were not able to propose a game, and chose manipulative or destructive actions. Twelve percent of children demonstrated a medium level of development of playing skills. They were able to propose one or two alternatives of socio-dramatic play or a play with rules and imagined development of the plot. Thirty-two percent of children possessed a high level of development of playing skills. They proposed several alternatives to socio-dramatic play, play with rules or dramatization play; described the course of the play and distribution of roles; and developed the plot consistently.

\begin{tabular}{lcccc}
\hline & Sample 1 & Sample 2 & $\mathbf{U}_{\text {emp. }}$ & $\mathbf{U}_{\mathbf{0 , 0 5}}$ \\
\cline { 2 - 5 } Development of playing skills & 2.4 & 1.3 & 31 & $34-46$ \\
\hline
\end{tabular}

\section{Frequency of conflict situations}

The frequency of conflict contacts and behavior in conflict situations were analyzed. 
The frequency of conflict contacts under natural conditions in both subsamples was low (Sample 1 - average score 2.11 points; Sample $2-1.85$ points).

\begin{tabular}{lcccc}
\hline & Sample 1 & Sample 2 & $\mathbf{t}_{\text {emp. }}$ & $\mathbf{t}_{\mathbf{0 , 0 5}}$ \\
\cline { 2 - 5 } Contacts in conflict situations & 2.11 & 1.85 & 0.8 & $2.05-2.76$ \\
\hline
\end{tabular}

Analysis of conflict resolutions in an assumed and in a real situation demonstrated that the majority of children (60\%) preferred a constructive approach and tried to come to an agreement that would be suitable for both partners, $28 \%$ of children ignored the conflict, and $12 \%$ of children behaved aggressively or abused and even threatened their partner (Sample 1 - average point 2.4; Sample 2 - average point 2.6).

\begin{tabular}{lcccc}
\hline & Sample 1 & Sample 2 & $\mathrm{U}_{\text {emp. }}$ & $\mathrm{U}_{\mathbf{0 , 0 5}}$ \\
\cline { 2 - 5 } Conflict resolution approach & 2.4 & 2.6 & 67 & $34-46$ \\
\hline
\end{tabular}

\section{Prosocial behavior}

Prosocial behavior was recorded during observation of joint activities of children (Sample 1 - average score was 2.57 points; Sample $2-2.35$ points). Sixty-one percent of children rendered positive altruistic assistance and offered their partner the use the elements of their own mosaic. Thirty-two percent of children acted pragmatically and shared their elements after their partner's request, but only after finishing their own task. Seven percent of children refused to help their partner verbally, but did not prevent the partner from taking the missing elements. No categorical refusal of helping another child was registered.

\begin{tabular}{lcccc}
\hline & Sample 1 & Sample 2 & $\mathbf{U}_{\text {emp. }}$ & $\mathbf{U}_{\mathbf{0 , 0 5}}$ \\
\cline { 2 - 5 } Prosocial behavior & 2.57 & 2.35 & 97 & $47-61$ \\
\hline
\end{tabular}

\section{Emotional response to peer influence}

An emotional response to peer influence was reviewed as the willingness and readiness of the child to perceive actions and react to other participants' propositions. In both Sample 1 and Sample 2, children demonstrated a medium level of response (i.e., did not always respond emotionally to actions and propositions of other children) (Sample 1 - average score 2.2 points; Sample $2-2.31$ points).

\begin{tabular}{lcccc}
\hline & Sample 1 & Sample 2 & $\mathrm{T}_{\text {emp. }}$ & $\mathrm{T}_{\mathbf{0 , 0 5}}$ \\
\cline { 2 - 5 } $\begin{array}{l}\text { Emotional response to peer } \\
\text { influence }\end{array}$ & 2.2 & 2.31 & 0,5 & $2.05-2.76$ \\
\hline
\end{tabular}

\section{Sociometric structure of the group}

Analysis of the sociometric structure of the group demonstrated the relations of sympathy/antipathy among the children. Overall, the total percentage of positive 
responses in both samples was $72.5 \%$ and, negative responses amounted to $27.5 \%$. In most cases, children experienced serious difficulties in explaining the reasons for their sympathy or antipathy. Most commonly, children gave brief answers, for instance: "we are friends", "we are not friends" or "I don't know".

\section{Peer-communication quality in teacher-directed and child-directed approaches}

We compared the peculiarities of communication of children who attend pre-primary school with child-directed and teacher-directed approaches. The following indices were measured: proactiveness, success in communication, development of playing skills, frequency of conflict contacts and ways of resolving conflicts, prosocial behavior, emotional response towards peer influence, and sociometric group structure. Significant differences among subgroups were indicated at various levels of development in playing skills and sociometric group structures $(\mathrm{p} \leq 0.05)$.

The development of playing skills of children from Sample 1 and Sample 2 were significantly different. The skill of entering socio-dramatic play or a game with rules, distributing roles, following them and developing the play's plot consistently were higher in Sample 1. Children from Sample 2 proposed fewer variations of socio-dramatic play, could not explain the course of the game as well, and the rules were also more complicated for them. They usually proposed the same set of games: cars, dolls, and so on (Sample 1 - the average number was 2.4; Sample 2 - the average number was 1.3 according to 3 -point scale from " 1 " to " 3 "). According to the results, these differences were significant based on the Mann-Whitney U-test $(\mathrm{p} \leq 0.05)$.

\begin{tabular}{lcccc}
\hline & Sample 1 & Sample 2 & $\mathbf{U}_{\text {emp. }}$ & $\mathbf{U}_{\mathbf{0 , 0 5}}$ \\
\cline { 2 - 5 } Development of play skills & 2.4 & 1.3 & 31 & $34-46$ \\
\hline
\end{tabular}

The results demonstrated that pre-school children showed better developed play skills in environments that applied the child-directed approach. The play skills of pre-school children experiencing the teacher-directed approach were less developed.

Analysis of the sociometric structure of the group made it possible to reveal the differences in the manifestation of sympathy and antipathy in both samples (childdirected and teacher-directed approaches). Thus, the number of joint choices differed significantly between the two samples $(\mathrm{p} \leq 0.05)$. In Sample $1(127)$, there were more common choices than in Sample 2 (97).

\begin{tabular}{lcccc}
\hline & Sample 1 & Sample 2 & $\mathbf{U}_{\text {emp. }}$ & $\mathbf{U}_{\mathbf{0 , 0 5}}$ \\
\cline { 2 - 5 } Number of joint choices & 127 & 97 & 45.5 & $47-61$ \\
\hline
\end{tabular}

The communication perception of children from Sample 1 was more adequate, and the atmosphere was healthier than in Sample 2. We believe that the child-directed approach facilitates more successful development of the perceptive component of communication with peers. 
According to the results, the teacher-child interaction (degree of freedom afforded to children, adult supervision, etc.) is important for the development of communicative and perceptual aspects of child communication with peers. The child-directed interaction allows peer-communication to form more adequately.

\section{Discussion}

Children often take initiative, but are not persistent. The vast majority of the interviewed children did not have issues with choosing partners, which testifies to the well-being of their communication. However, more than half of the children could not think or offer any option of role play or games with rules.

In rare cases, children became involved in conflict. Most children showed constructive ways to resolve conflicts, provide assistance to a peer, and treat him as a partner. Children found it difficult to explain their sympathy. The number of positive choices outweighed the number of negative choices.

Child-led communication benefits the development of play skills and sympathetic peers. This ability can provide a solid basis not only for the development of communicative competence but also for the formation of stable self-esteem, educational initiatives and success at school (Nisskaya, 2013). Additionally, the childdirected approach has no unwanted effects. Child-led communication is a way to facilitate the development of play skills in preschoolers, as well as to develop focus, patience, and so on.

According to the results, the teacher-child interaction (the degree of freedom provided to children under adult supervision, etc.) is essential for the development of communicative and perceptual aspects of communication of children with peers. The interaction of children in peer to peer communication allows for adequate development.

The authors who study the problems of the educational environment (Rubtsov V. V., Slobodchikov V. I., Ulanovskaya I. M., jasvin V. A., etc.), teacher-child communication as a component of the educational environment (Petrovsky V. A., Rubtsov V. V., Birch, S. H., Downer, J., Sabol, T. J., Hamre, Ladd, G. W., LocasaleCrouch, J., DeCoster, J., \&Pianta, R. etc.), and the quality of pre-school educational environments (Shiyan, 2013) agree that adults influence the development of children. Our study clarifies how teacher-directed and child-directed approaches are related to various components of preschoolers' peer-communication, such as sociometric status, success in peer-communication, play skills, proactiveness, and behavior during conflict, and proves the considerable potential of the child-directed approach in child development and education.

\section{Conclusion}

Peer-communication from the ages of four to six years old is at the stage of formation and evolvement. Particularly, the sociometric structure of a group is starting to form. For many children, the choice of a partner is an easy task. Children know who they want to choose and who they do not want to communicate with. In most cases, children treat their peers positively. Positive choices surpass negative choices. However, the awareness of these choices is not high. Children experience difficulties in explaining the nature of their sympathies and antipathies. 
Most children are successful in peer-communication and have many partners and counterparts to choose from. Play skills and proactiveness are formed insufficiently. Most children cannot master a wide range of games and play skills and prefer a passive or subdued role. Children seldom take part in conflicts. Most of them are able to resolve conflict situations in a constructive manner. Few children demonstrate aggression.

The connection between teacher-directed and child-directed approaches and peer-communication quality has been proven. The child-directed approach meets the specific age needs of children. It is well known that play is the leading activity at the preschool age. Therefore, children who have an opportunity to practice various games, roles and rules achieve a higher level of development of play skills.

It was demonstrated that teacher-directed and child-directed approaches impact the sociometric structure of the group and attraction. The child-directed approach is positively connected with the intensity of common peer sympathies and antipathies. We believe that it occurs because children have the opportunity to play with peers and get to know each other better as well as make decisions on who they like or do not like.

We believe that the conditions under which children do not have to compete in classes provide more positive attitudes among children.

Therefore, the child-directed approach positively impacts the development of children's peer-communication.

This study showed that this approach helps children build harmonious peercommunication in this age group compared with children in kindergarten, who experience the teacher-directed approach. The results indicate that we should continue to facilitate the spread of the child-directed approach, use it in programs for preschoolers, create methodical recommendations for teachers, and assess the quality of preschool education. Additionally, our findings support that teachers should communicate with children more freely, allow them to follow their interests, encourage children's independence and activity, and allow children to spend more time playing.

This study clarified particular practices in child-centered and teacher-centered approaches. It is important to know how various teaching practices affect peerinteraction. Additionally, several additional variables should be evaluated to further this research. For example, it is necessary to control for the influence of family culture, level of development of children's speech, duration of study in preschool, cultural background, and parent-child relationships.

\section{Limitations}

We understand that preschoolers' peer-communication is affected not only by preschool conditions but also by their family background, personality, and social environment (cultural, traditional, ethnic, etc.). This research should be continued and involve further investigations.

The above mentioned results could be used for preschool education development, particularly in regard to the teacher-student interaction. Moreover, childparent relationships can be enriched by supporting child activity and initiative. 


\section{References}

Anders, Y. (2014). Literature Review on Pedagogy, Literature Review for the OECD. Paris, OECD.

Birch, S. H., \& Ladd, G. W. (1998). Children's interpersonal behaviors and the teacher-child relationship. Developmental Psychology, 34, 934-946. doi: 10.1037/0012-1649.34.5.934

Bulychova, A. I. (Ed.). (2012). Razvitie +: Primernaya osnovnaya obshcheobrazovatel'naya programma doshkolnogo obrazovaniya [Development +: the Approximate basic educational program of preschool education]. Moscow: Razvite.

De Haan, A. K. E., Elbers, E., \& Leseman, P. P. M. (2014). Teacher- and child-managed academic activities in preschool and kindergarten and their influence on children's gains in emergent academic skills. Journal of Research in Childhood Education, 28(1), 43-58. doi: $10.1080 / 02568543.2013 .851750$

Downer, J., Sabol, T. J., \& Hamre, B. (2010). Teacher-child interactions in the classroom: Toward a theory of within and cross-domain links to children's developmental outcomes. Early Education \& Development, 21(5), 699-723. doi: 10.1080/10409289.2010.497453

Eisenberg, N., \& Mussen, P. H. (2011). The roots of prosocial behavior in children, Cambridge, UK: Cambridge University Press.

Elkoninova, L. I. (2014). Polnota razvitiya syuzhetno-rolevoi igry [Wholeness of the role-played games]. Kul'turno-istoricheskaya psikhologiya [Cultural-Historical Psychology], 10(1), 54-61.

Federalnyi gosudarstvennyi obrazovatelnyi standart doshkolnogo obrazovaniya [Federal State educational standard of preschool education]. Retrieved from: http://xn--80abucjiibhv9a. xn--p1ai/documents/6261

Flavell, J.H. (1981). Cognitive monitoring. In W. P. Dickson (Ed.), Children's oral communication skills (pp. 35-60). New York: Academic Press.

Graves, S. L., \& Howes, C. (2011). Ethnic differences in social-emotional development in preschool: the impact of teacher-child relationships and classroom quality. School Psychology Quarterly, 26(3), 202-214. doi: 10.1037/a0024117

Heckman, J., \& Tremblay, R. (2006). The case for investing in early childhood. A snapshot of research by University of Chicago, USA \& University of Montreal, Canada. Sydney: The Smith Family Research and Development.

Kuger, S., Sechtig, J., \& Anders, Y. (2012). Kompensatorische (Sprach) Förderung: Was lässtsichaus US-amerikanischen Projektenlernen? [Compensating (language) programs: What can be learnt from the US projects?]. FrüheBildung, 1(4), 181-193. doi: 10.1026/2191-9186/ a000061

Lavrentieva, T. V. (Ed). (2002). Psikholog v doshkolnom uchrezhdenii. Metodicheskie rekomendatsii $k$ prakticheskoy deyatelnosti [Psychologist in the preschool institution. Methodical guidelines for the practice-oriented activity]. Moscow: Gnom and D.

Lerkkanen, M.-K., Kiuru, N., Pakarinen, E., Viljaranta, J., Poikkeus, A.-M., Rasku-Puttonen, H.,... Nurmi, J.-E. (2012). The role of teaching practices in the development of children's interest in reading and mathematics in kindergarten. Contemporary Educational Psychology, 37(4), 266-279. doi: 10.1016/j.cedpsych.2011.03.004

Locasale-Crouch, J., DeCoster, J., \& Pianta, R. (2013, April). Transition to kindergarten experiences and children's growth over the school year: The role of the teacher-child relationship. Paper symposium at the Society for Research on Child Development Biennial Conference, Seattle, W.A. Retrieved from: http://www.srcd.org/sites/default/files/documents/2013_ srcd_program_book.pdf

Marcon, R. (1999). Differential impact of preschool models on development and early learning of inner-city children: A three cohort study. Developmental Psychology, 35(2), 358-375. doi: 10.1037/0012-1649.35.2.358

McCain, M., \& Mustard, J.F. (1999). Early years study. Toronto: Publications Ontario. 
Petrovsky, V.A. (1996). Subektnost: novaya paradigma v obrazovanii [Subjectivity: the new paradigm in education]. Psikhologicheskaya nauka i obrazovanie [Psychological Science and Education], 3, 100-109.

Pianta, R. C., Rimm-Kaufman, S. E., \& Cox, M. J., (1999). An ecological approach to kindergarten transition. In R. C. Pianta \& M. J. Cox (Eds.), The transition to kindergarten (pp. 3-12). Baltimore: Brookes.

Polivanova, K. N. (2012). Izmenenie praktik razvitiya i ego posledstviya [Changing developmental practices and its implications]. In Fenomenologiya sovremennogo detstva. Sbornik nauchnykh trudov $v$ trekh chastyakh [The phenomenology of modern childhood. Collection of scientific articles in three parts]. Moscow: FIRO.

Rubtcov, V.V. (2005). Sotsialnoe vzaimodeistvie i obuchenie: Kulturno-istoricheskii kontekst [Social interaction and learning: a cultural-historical context]. Kulturno-istoricheskaya psikhologiya [Cultural-Historical Psychology], 1, 14-35.

Scott-Little, C., La Paro, K. M., Thomason, A. C., Pianta, R. C., Hamre, B., Downer, J., ... Howes, C. (2011). Implementation of a course focused on language and literacy within teacher-child interactions: Instructor and student perspectives across three institutions of higher education. Journal of Early Childhood Teacher Education, 32(3), 200-224. doi: 10.1080/10901027.2011.594489

Shiyan, O.A. (2013). Novye predstavleniya o kachestve doshkol'nogo obrazovaniya i mekhanizmy ego podderzhki: mezhdunarodnyi kontekst [New views on the quality of preschool education and its support mechanisms: international context]. Sovremennoe doshkolnoe obrazovanie. Teoriya i praktika [Contemporary preschool education. Theory and Practice], 5, 68-78.

Smirnova, E.O. (1996). Problemy obshcheniya rebenka i vzroslogo v rabotakh L.S. Vygotskogo i M.I. Lisinoi [Child and adult communication problems in the works of L. S. Vygotsky's and M. I. Lisina]. Voprosy psikhologii [Issues in Psychology], 6, 76-87.

Smirnova, E.O., \& Galiguzova, L.N. (2005). Sostoyanie igrovoi deyatel'nosti sovremennykh doshkolnikov [The state of the gaming activities of modern preschoolers]. Psikhologicheskaya nauka i obrazovanie [Psychological Science and Education], 2, 76-86.

Smirnova, E.O., \& Kholmogorova, V.M. (2005). Mezhlichnostnoe obshchenie doshkolnikov. Diagnostika, problemy, korrektsiya [Interpersonal relations of preschool children. Diagnostics, problems, correction]. Moscow: Vlados.

Sobkin, V.S., \& Skobeltsina, K.N. (2012). Igrovaya deyatelnost detej doshkolnogo vozrasta: Sovmestnaja igra s roditeljami, igrovye predpochtenija, ljubimye igrushki [Play activity of preschool children: Joint play with parents, game preferences and favorite toys]. Zhurnal Sibirskogo Federalnogo Universiteta. Seriya "Gumanitarniye nauki" [Journal of Siberian Federal University. Series "Humanities"]. 5, 1602-1615.

Stipek, D., Feiler, R., Daniels, D., \& Sharon, M. (1995). Effects of different instructional approaches on young children's achievement and motivation. Child Development, 66(1), 209-223. doi: $10.2307 / 1131201$

Tartas, V., Baucal, A., \& Perret-Clermont, A.-N. (2010). Can you think with me? The Social and cognitive conditions and the fruits of learning. In C. Home \& K. Littletown (Eds.), Educational Dialogues: Understanding and Promoting Productive Interaction (pp. 64-82). New York: Routledge.

Vygotsky, L. S. (2008). Pedagogicheskaya psikhologiya [Pedagogical Psychology]. Moscow: AST. (Original work published 1926)

Zaporozhets, A.V., \& Lisina, M.I. (1974). Razvitie obshcheniya u doshkolnikov [Development of preschoolers' communication]. Moscow: Pedagogika. 